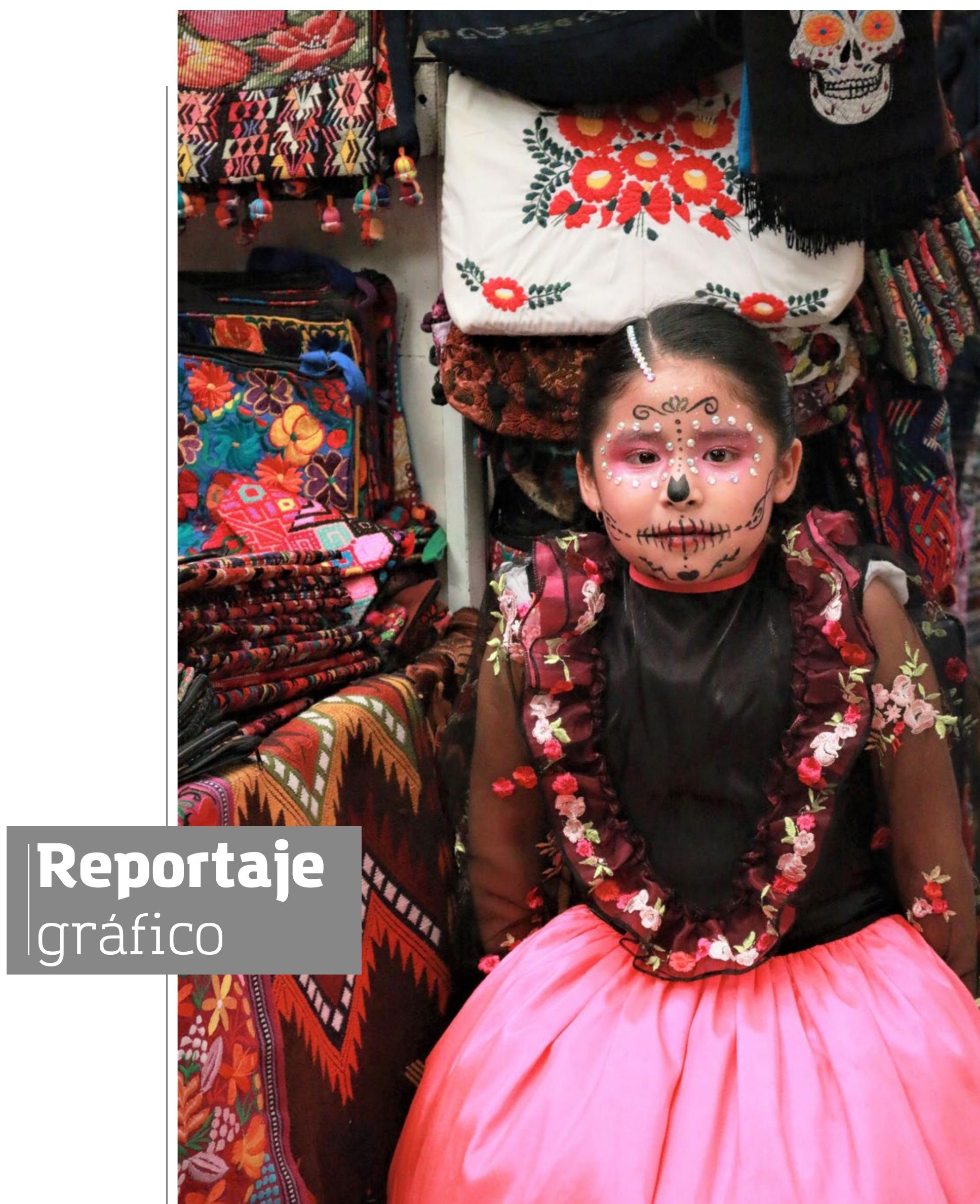




\section{México es un elote \\ y aquí solo 15 granos}

http://dx.doi.org/10.18566/comunica.n43.a08

Fecha de recepción: 1 de octubre de 2020

Fecha de aceptación: 13 de noviembre de 2020

"De ninguna manera volveré a México. No soporto estar en un país más surrealista que mis pinturas".

comunicación

número 43

Julio - diciembre

2020 | pp. 107-118

\section{Gloria N.}

\section{Ramírez-Oliveri}

Comunicadora social

periodista. Magister en

Liberal Arts-Spanish de

California State University

Northridge (CSUN). Tutora

de español e investigadora

del programa de Periodismo

en español de la CSUN.

gloria.oliveri.881@my.csun.

edu

Las fotografías que ilustran este artículo fueron tomadas en México en noviembre del año 2019, 10 meses antes de que el COVID-19 llegara a esas tierras como otro "conquistador" (nada cortés) a causar dolor y muerte. Al relatar los abusos cometidos por los enviados de Carlos I de España durante la conquista de México, el fraile español Bartolomé de las Casas refirió 20 millones de víctimas consecuencia del sometimiento impuesto por Hernán Cortés y los hombres a su mando (1519-1521). Cinco siglos después, el pueblo mexicano no se recupera de los efectos de la violencia y la desigualdad social.

Con casi 700.000 víctimas, el COVID ha sido menos cruel que los enviados de la corona española. Recuperar la memoria histórica es un deber de justicia frente a infamias que, como la conquista de México, nunca debieron ocurrir. Y aunque la "horrible noche" tampoco ha cesado, todavía este país surrealista y mágico sigue siendo uno de los lugares más extraordinarios y encantadores del planeta; al contrario de lo que alguna vez dijo Dalí, a México siempre hay que volver.

Las imágenes que acompañan este artículo son, entonces, registros de la infinita gama de realidades que se descubren al explorar algunos lugares de México y de su capital, antes de que el virus que trastornó todo impusiera nuevas leyes para vivir el presente y proyectar el futuro.

\section{Mi versión incompleta de México}

Hay quienes pueden explicar lo que ni ellos mismos entienden. Yo no lo consigo. Por tal razón, cuando se trata de comprender algo, acudo a métodos 
o analogías que yo misma me invento para dar cuenta de todo lo que me interesa como reportera gráfica y documentalista.

En esta ocasión, en un elote, mazorca o choclo, según el país, encontré la respuesta que necesitaba para presentar mis impresiones de un país fantástico, veleidoso, seductor y repleto de contrastes deslumbrantes. En sentido real y figurado, el aspecto de esta gramínea que se cultiva hace más de 10.000 años en la tierra de los aztecas me resultó fundamental para explicar y explicarme el país. La planta de maíz, cuyo nombre científico es Zea mays, no solo es la protagonista de la gastronomía mexicana, sino la analogía que me reveló que México es la mazorca, la totalidad, y para conocerlo habrá que desgranarlo.

Ni el más desocupado cocinero de este mundo cuenta los granos del elote que se va a comer. Sin embargo, yo tuve que hacerlo para ofrecer esta versión tan limitada de un país tan difícil de definir. No por casualidad se ha dicho que "el maíz es la más noble planta mexicana" y que la relación que tiene su pueblo con ella trasciende las fronteras culinarias, ecológicas y hasta místicas. Tortillas, tlacoyos, itacates, tacos, sopes, chalupas, huaraches, chilaquiles, enchiladas, pozole, tamales; pero... ¡¡jo!:

-No se confunda, Panchita, que México es mucho más que su deliciosa comida.

En mi caso, verán lo que descubrí al desgranar la mazorca, al observar algunos detalles de la totalidad.

Sin embargo, debo aclarar que cada una de estas fotografías solo cumple el propósito de introducir o abrir la puerta a cada una de esas realidades. Lo que uno descubre en el empeño de "retratar a México" es una infinita gama de posibilidades, tan variadas y diversas como todos los granos que nadie cuenta al saborear un elote. Espero haberme explicado, porque la analogía ya terminó.

De manera que lo que intento dar a entender con esta reducida selección es mi versión incompleta de México, la cual, según se me indicó, no debe superar las 15 imágenes. En todo caso, es más fácil tomarlas que elegir las que convienen. 
México es la Virgen de Guadalupe.

La Virgen de Guadalupe tiene la piel trigueña y los ojos oscuros.

Su fisonomía reproduce los rasgos de la población mestiza

de la "Nueva España”. Esta "virgen morena" es la protagonista de la fe católica y de la iconografía popular del país.

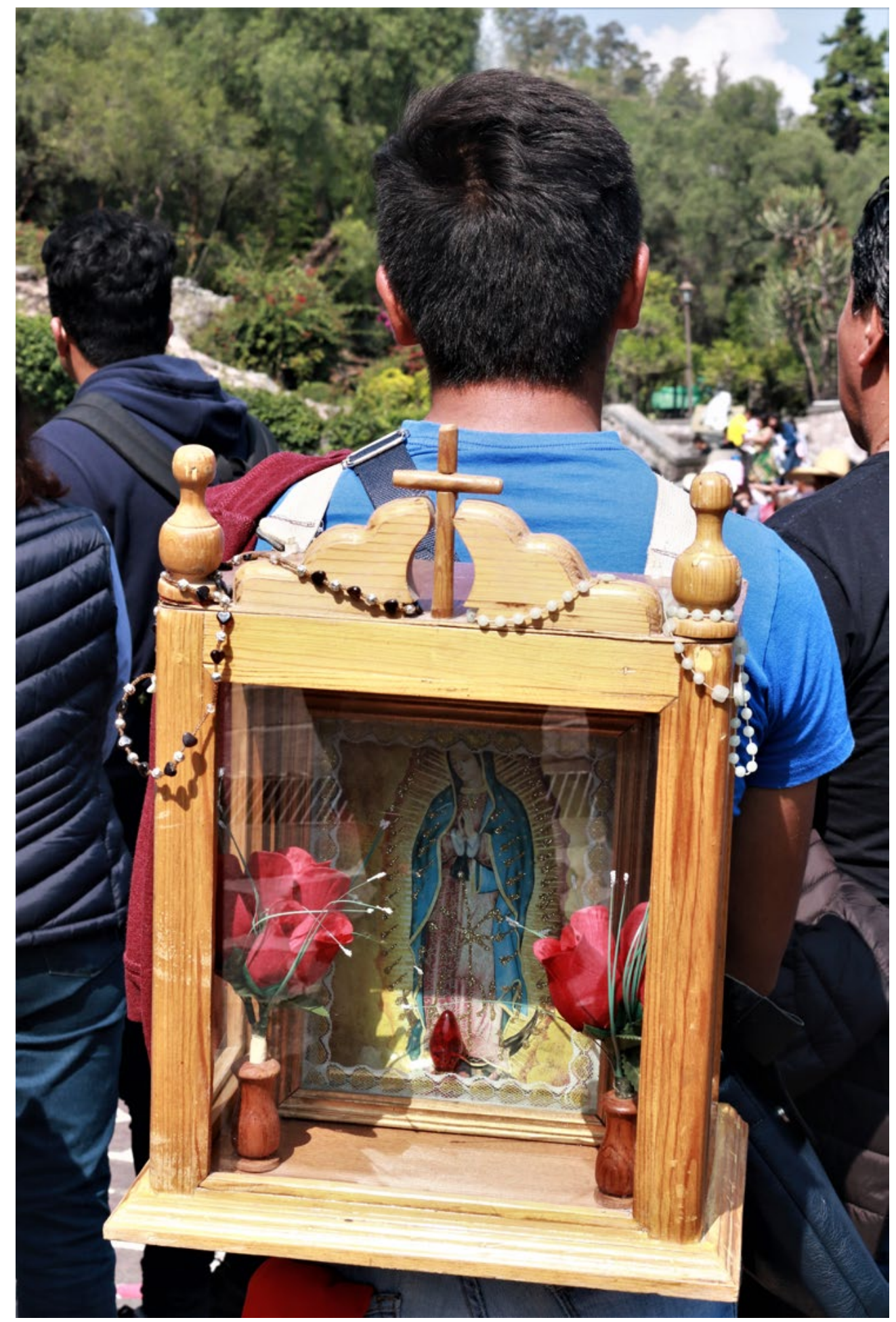


México es un país de museos y cultura.

Según datos del Sistema de Información Cultural (SIC) de México,

la ciudad tiene $\mathbf{1 5 6}$ museos. El Museo Nacional de Antropología

es uno de los más famosos del mundo.

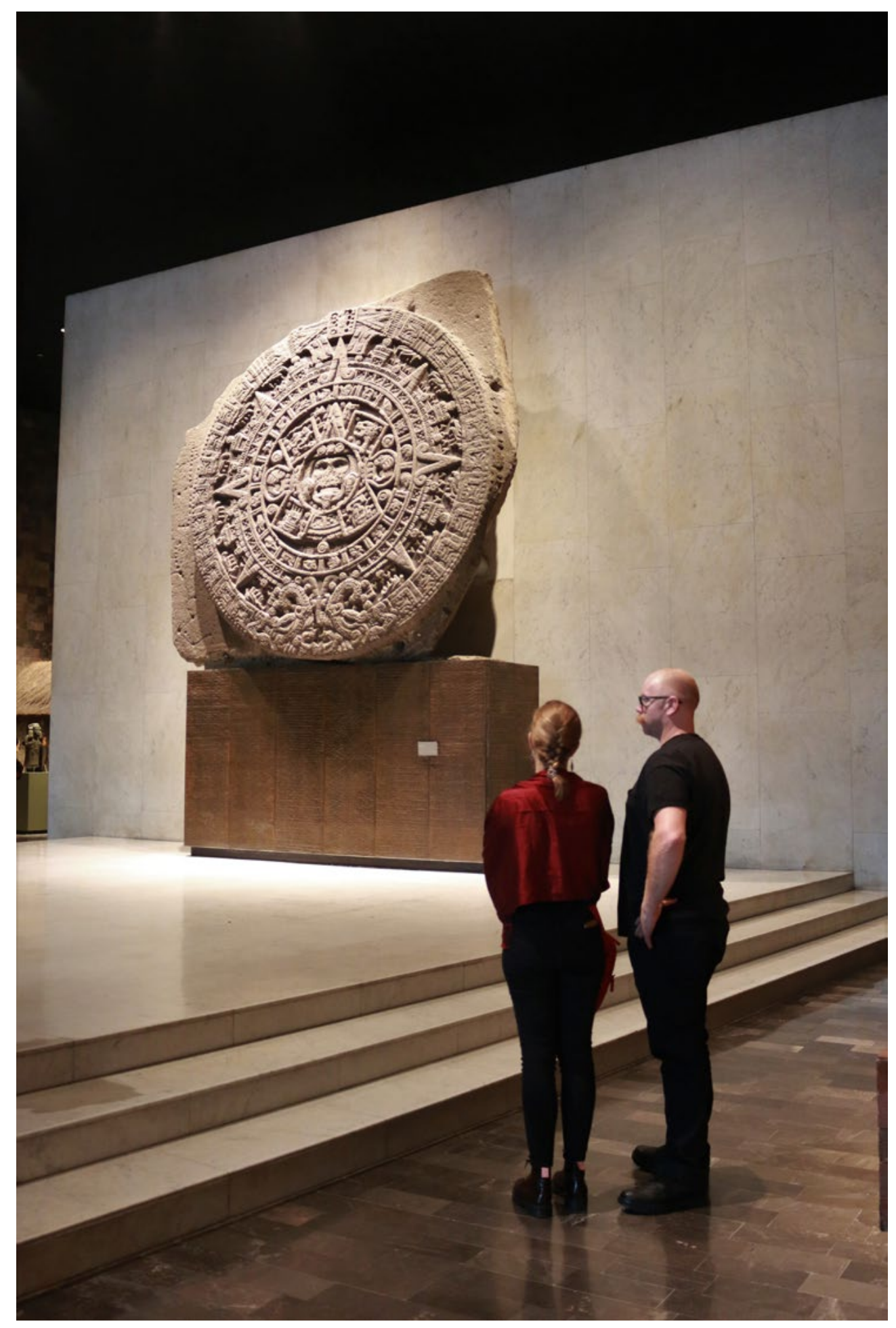




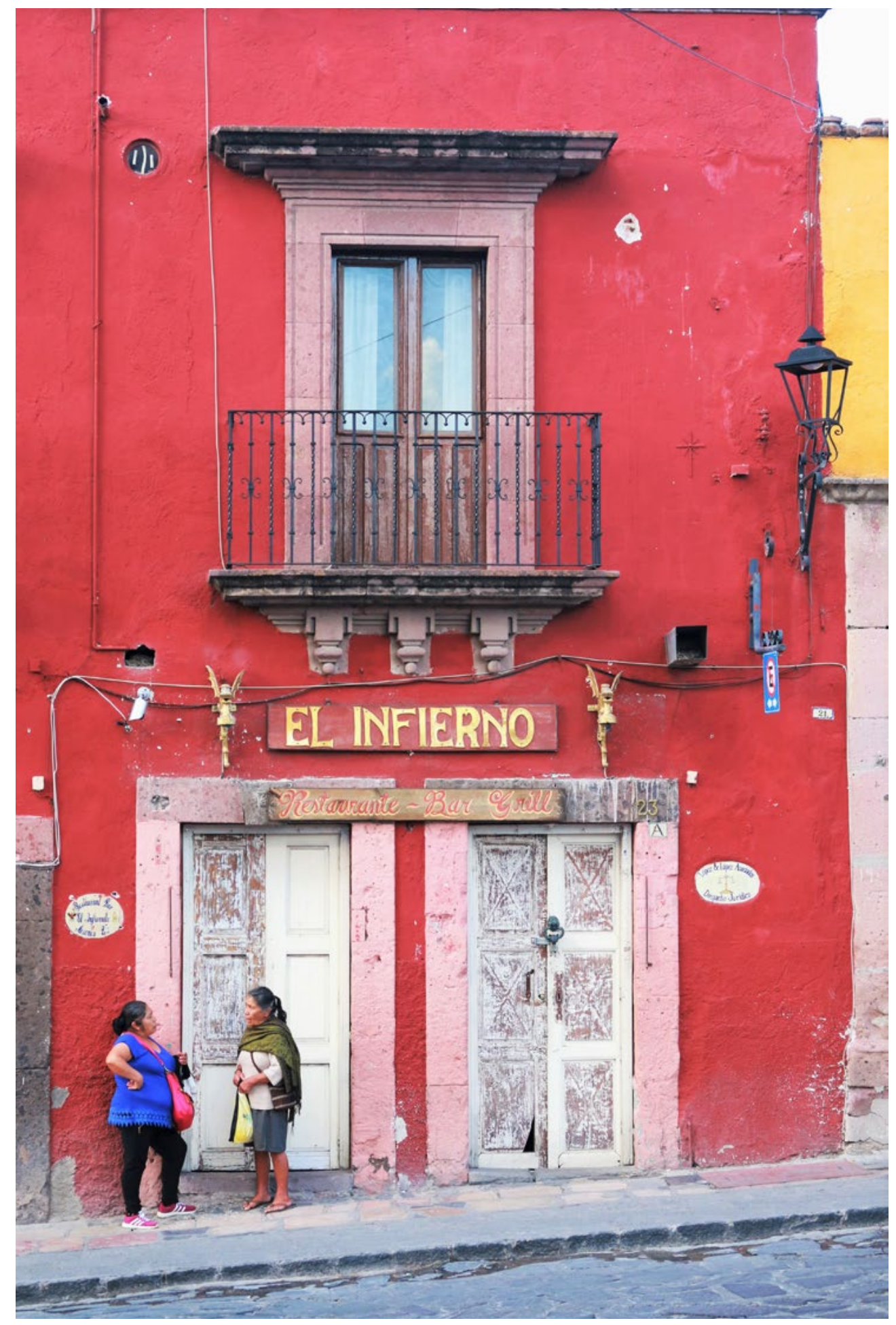

México es un enigma y patrimonio de la humanidad. 
comunicación

número 43

Julio - diciembre

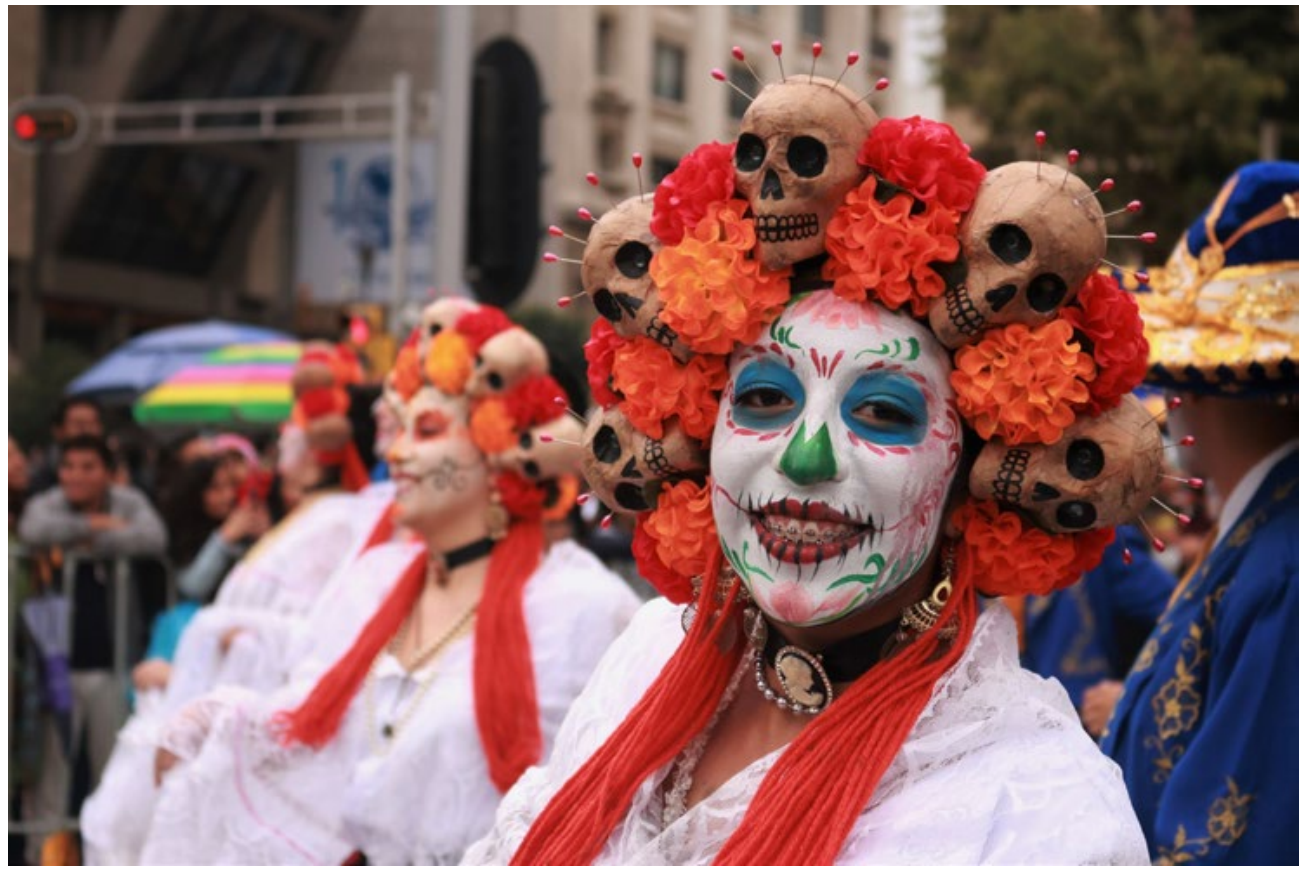

México es un carnaval.

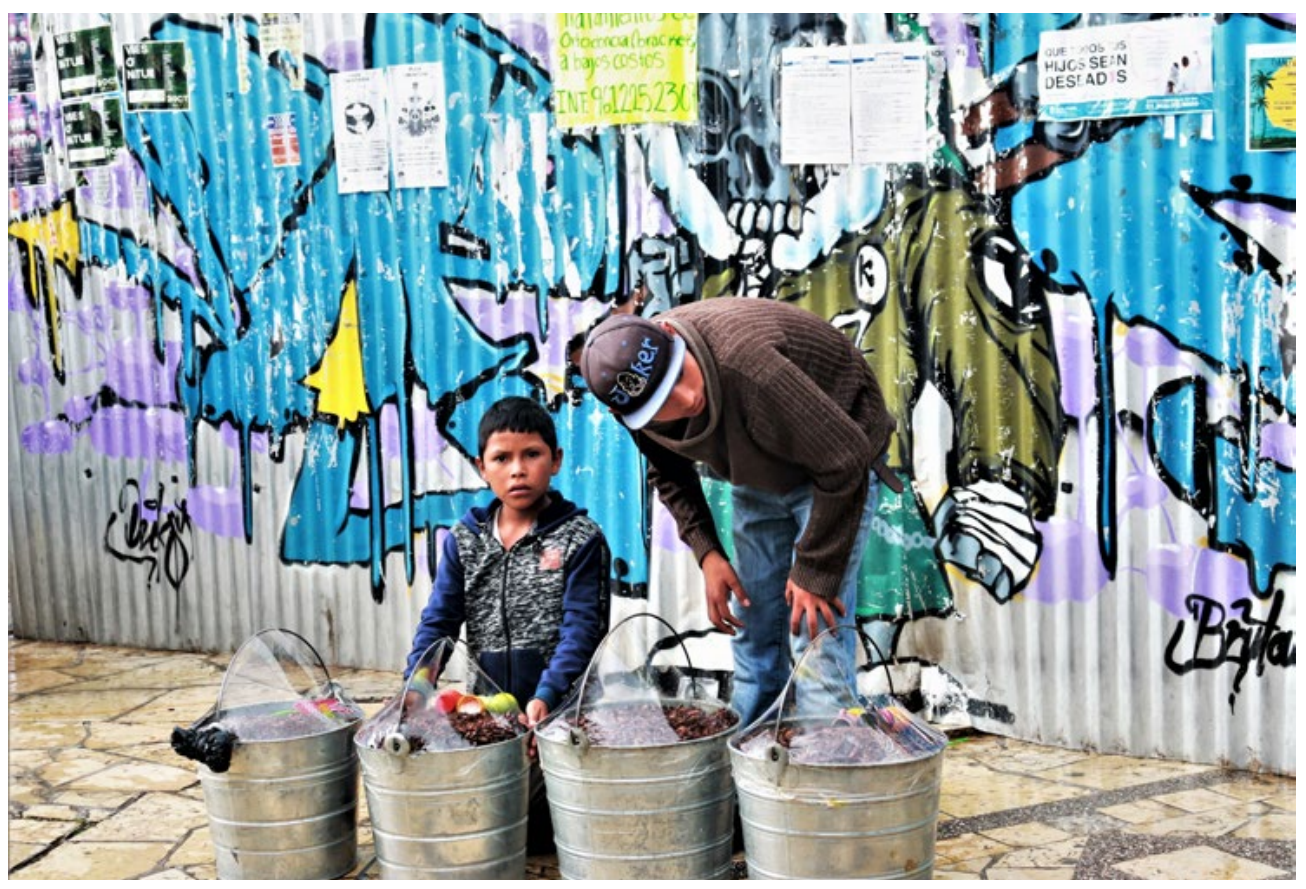

México son sus niños trabajadores. 


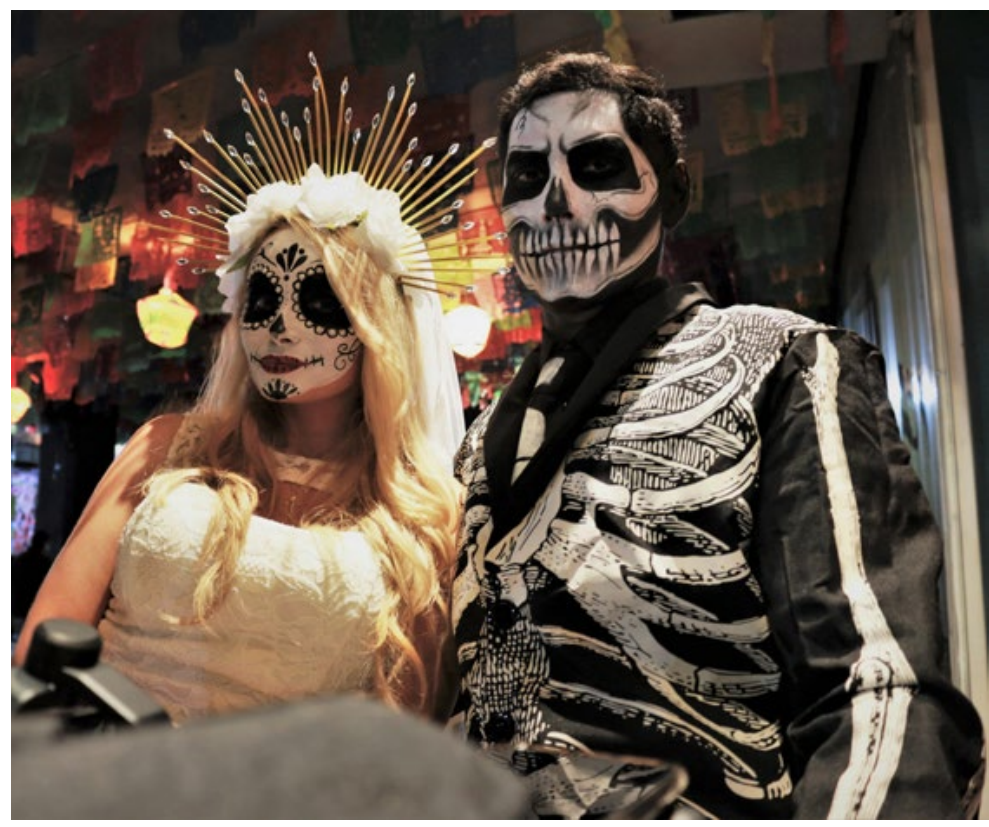

comunicación

número 43

Julio - diciembre 2020

México es la celebración del Día de los Muertos.

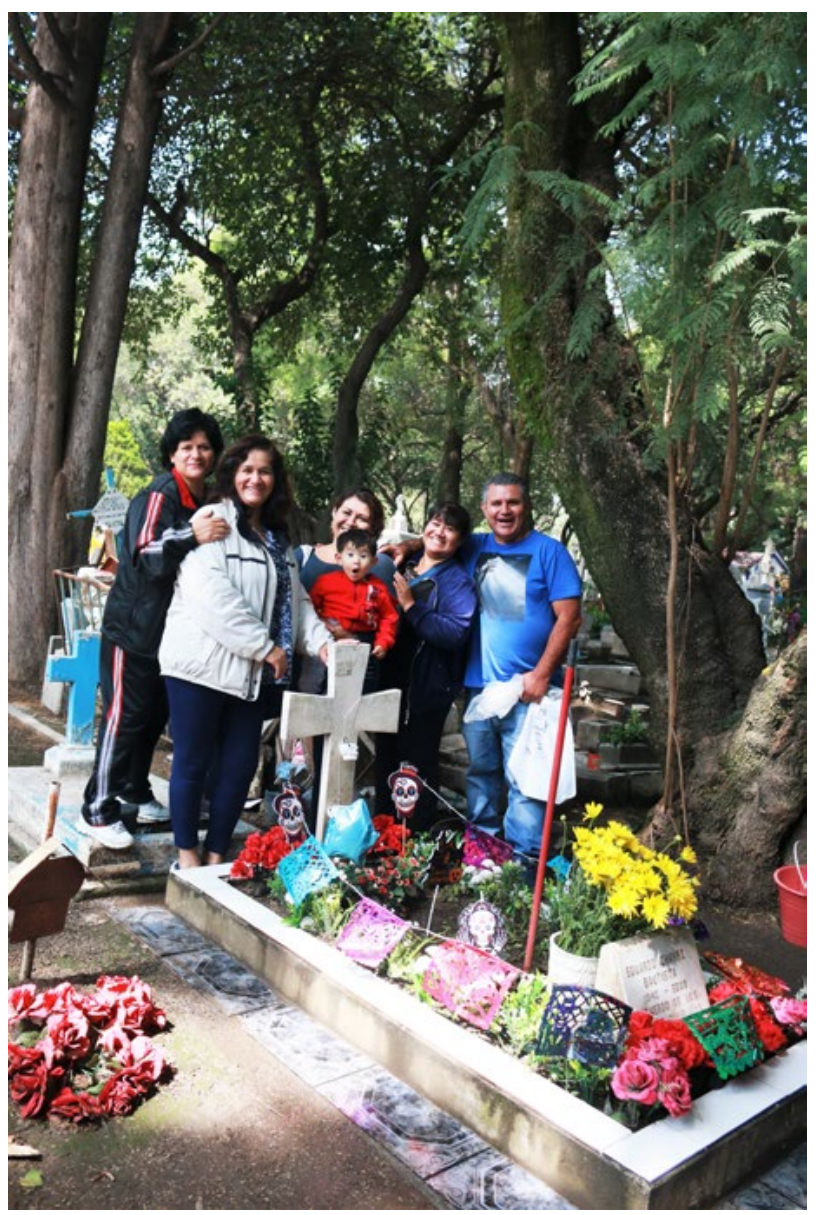

México es un tributo a la familia y a la memoria de sus muertos.

Pose de la familia Chávez Velázquez en uno de los cementerios de la Ciudad de México. Como parte de la celebración del Día de los Muertos, ellos visitan la tumba de sus padres. Este tributo incluye la decoración de las tumbas, la interpretación de canciones y el mejor momento para recordar a sus seres queridos. 
comunicación

número 43

Julio - diciembre

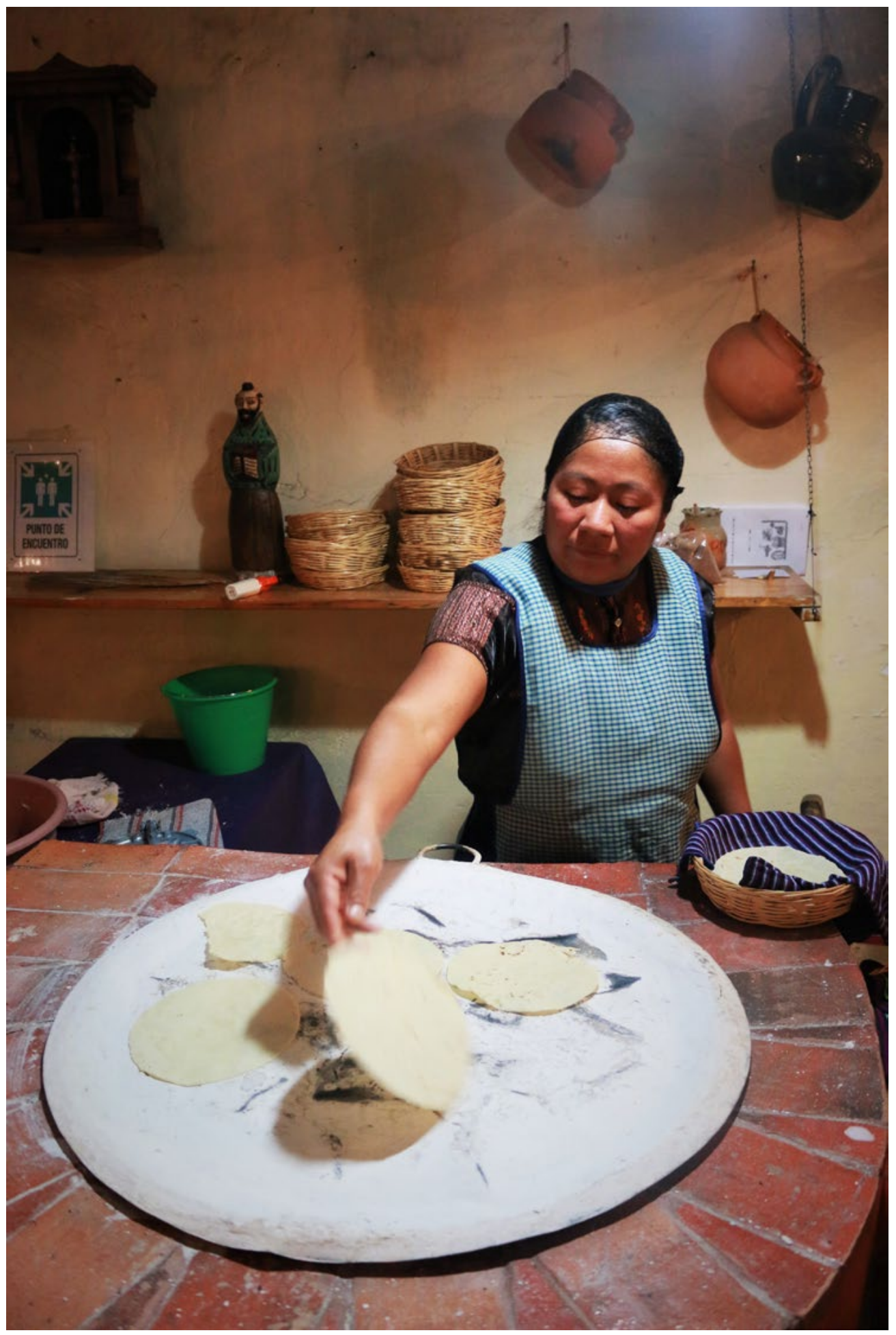

México es su comida. 
comunicación

número 43

Julio - diciembre

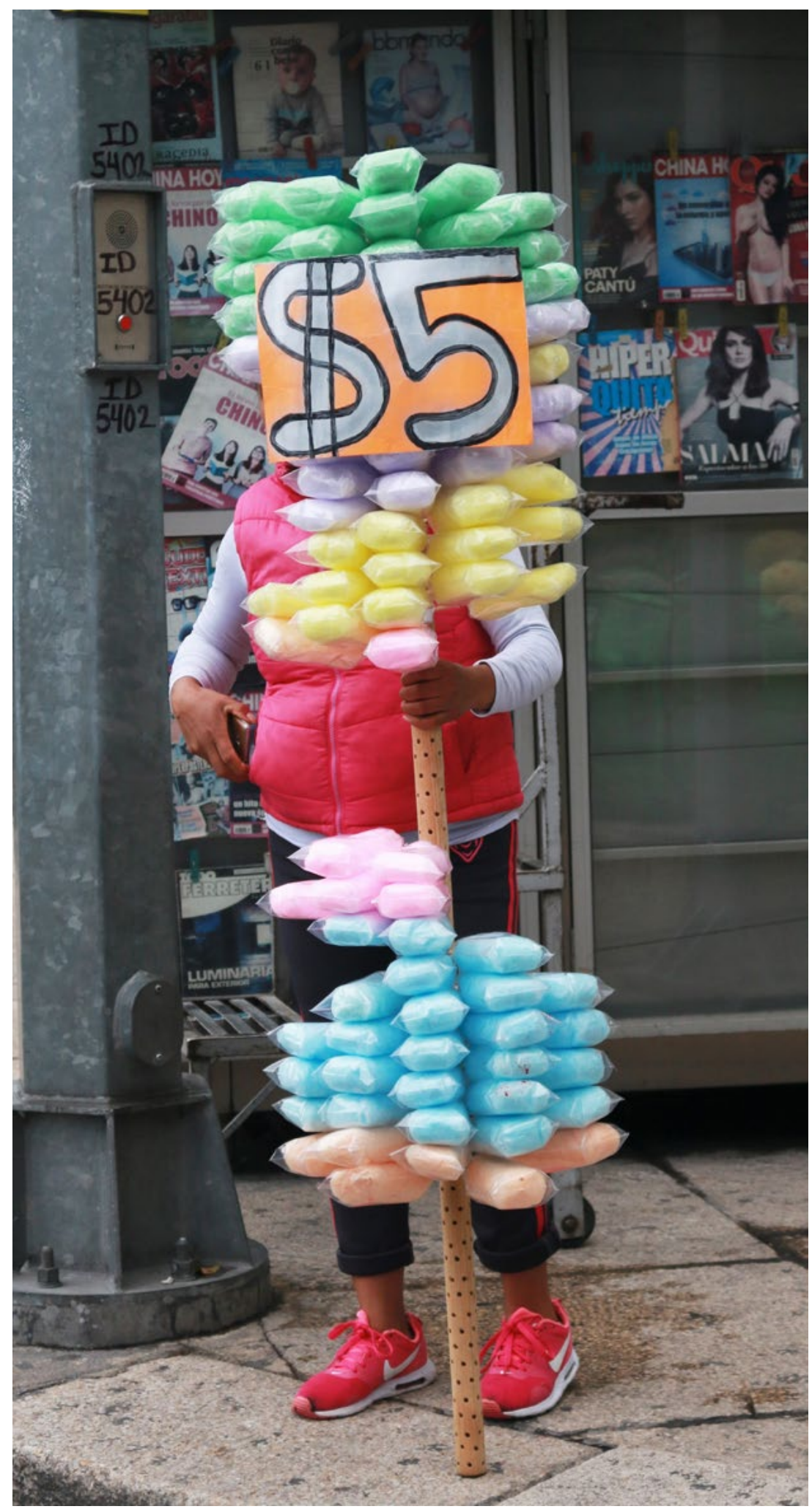

México es su gente. 


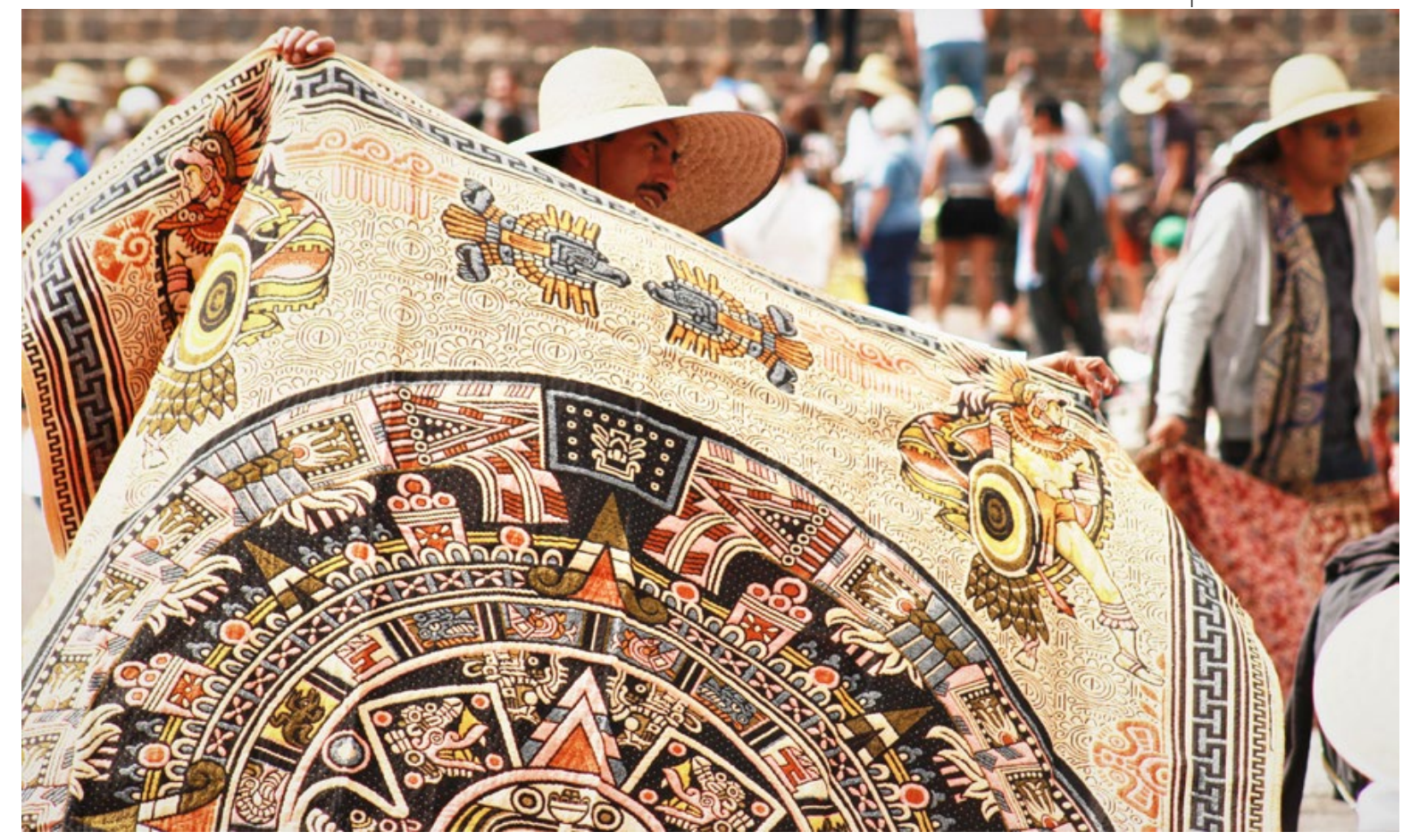

México es su artesanía.

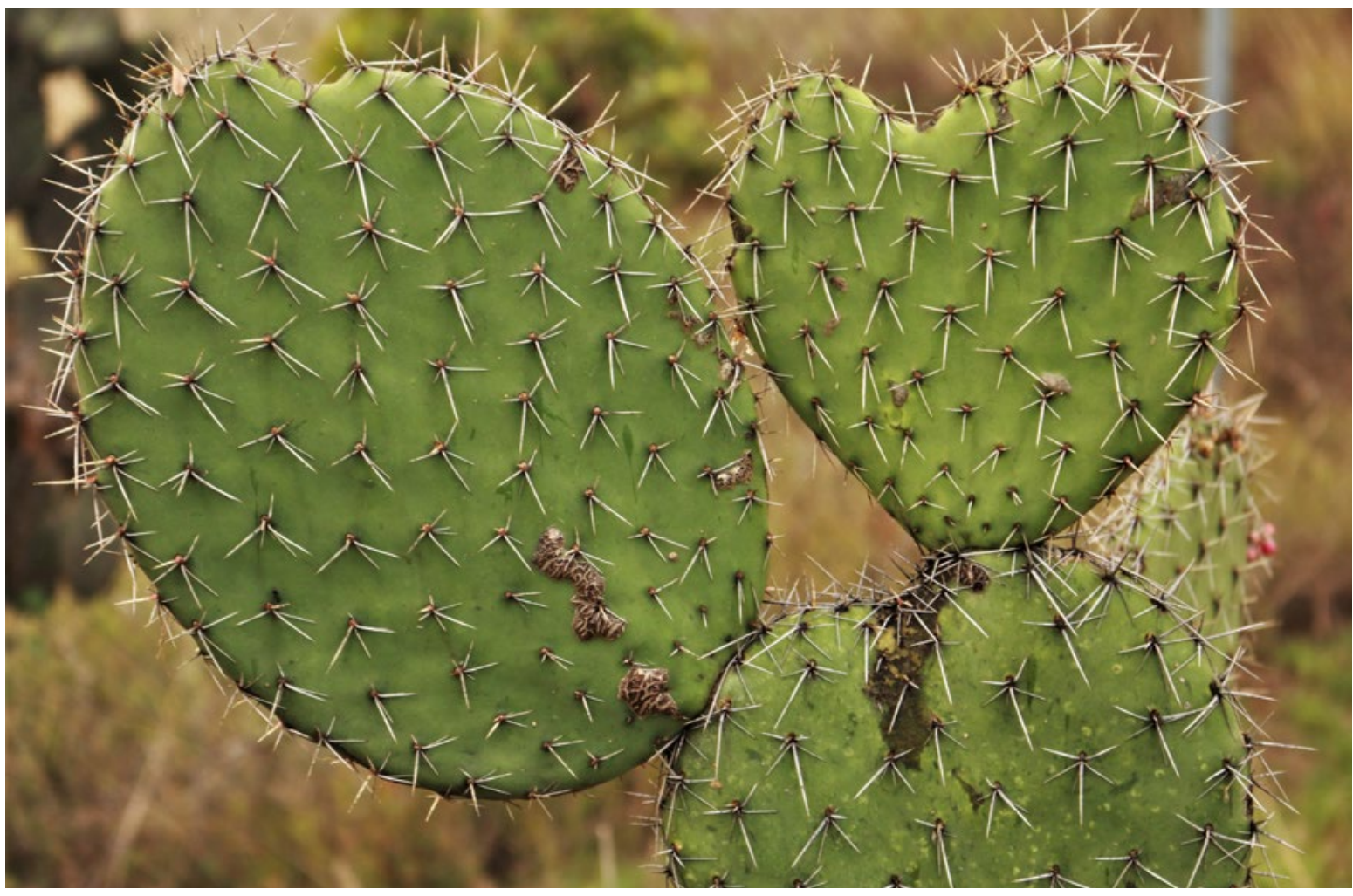


Comunicación

número 43

Julio - diciembre

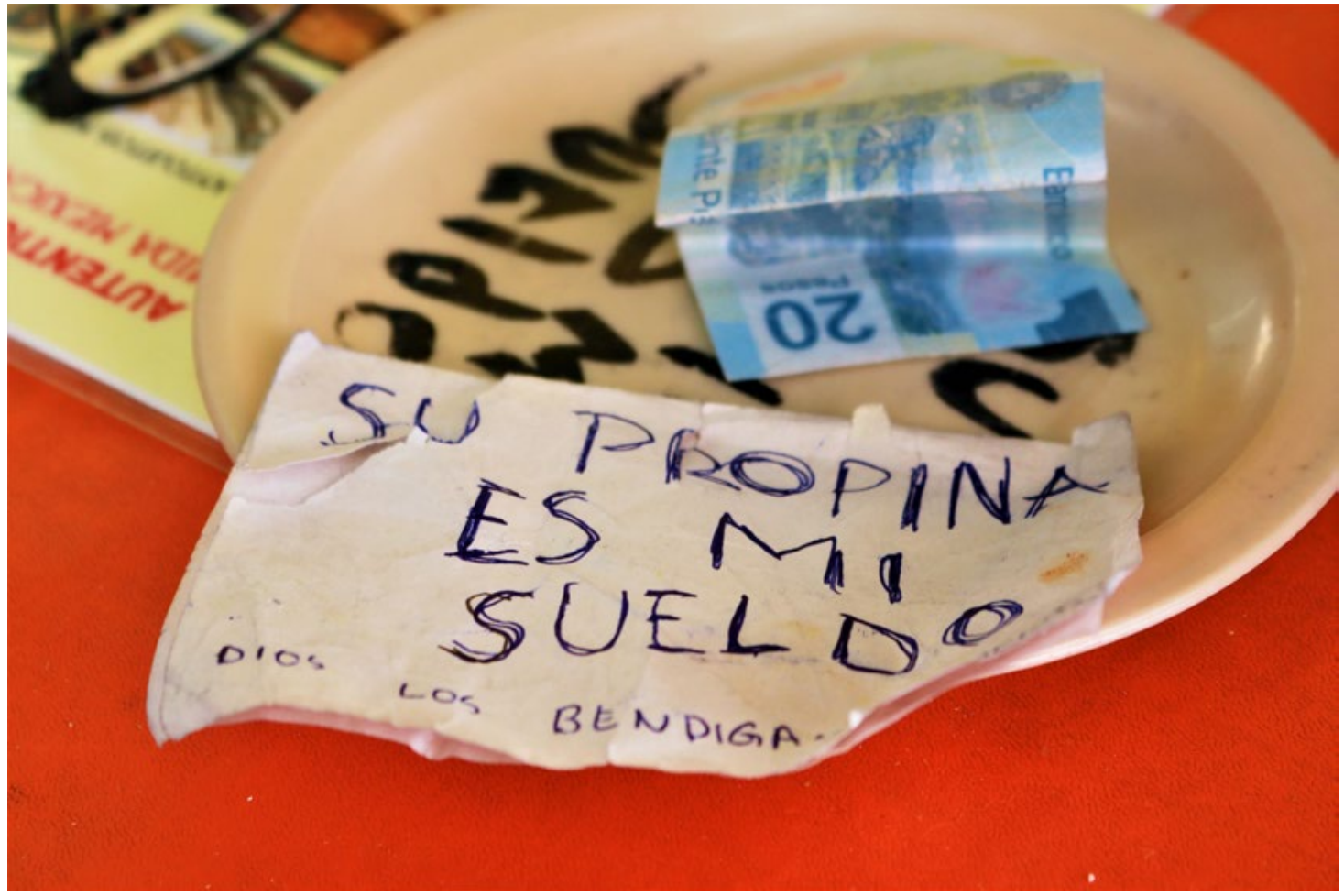

México es la "ley del rebusque".

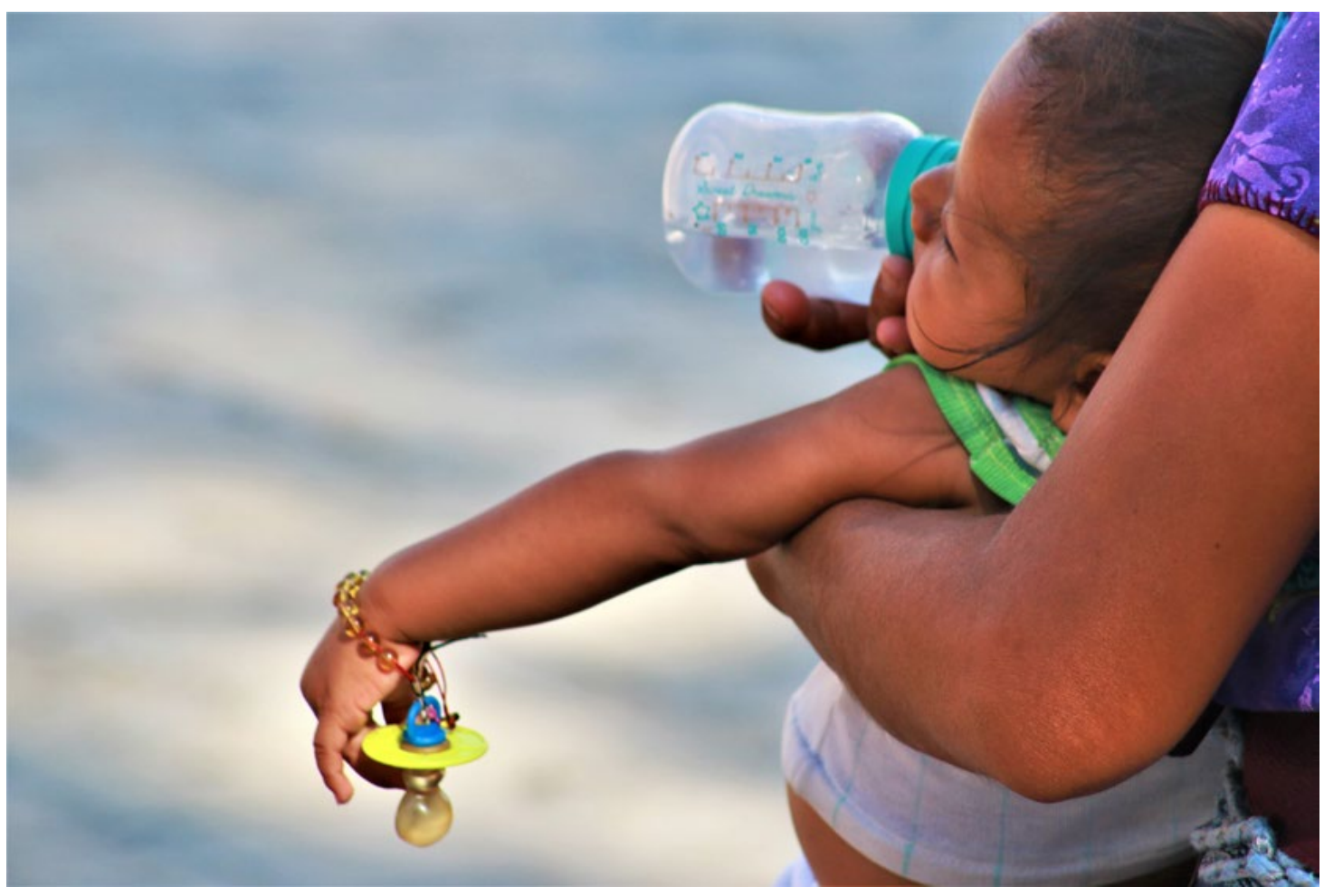




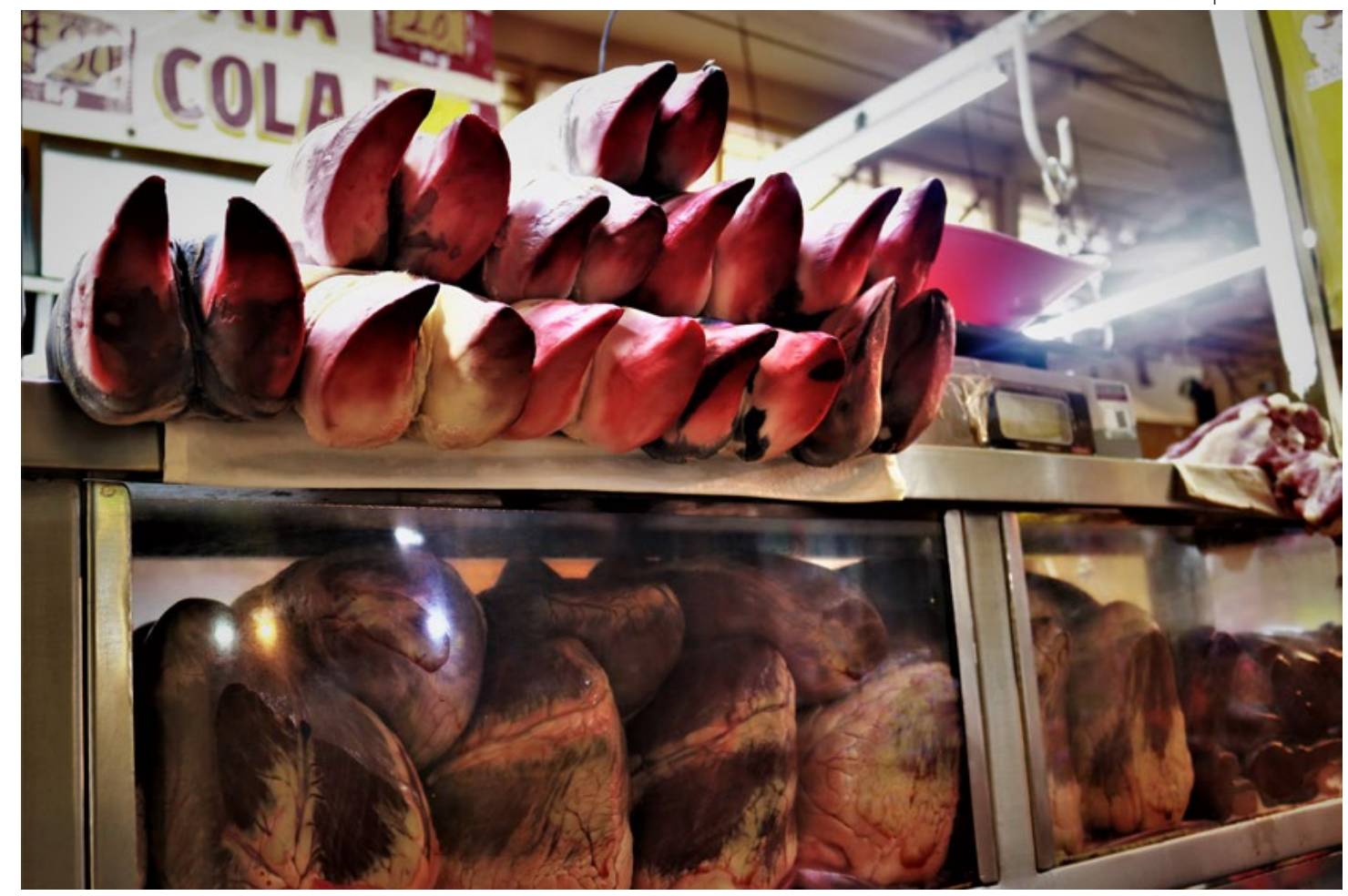

México es una carnicería.

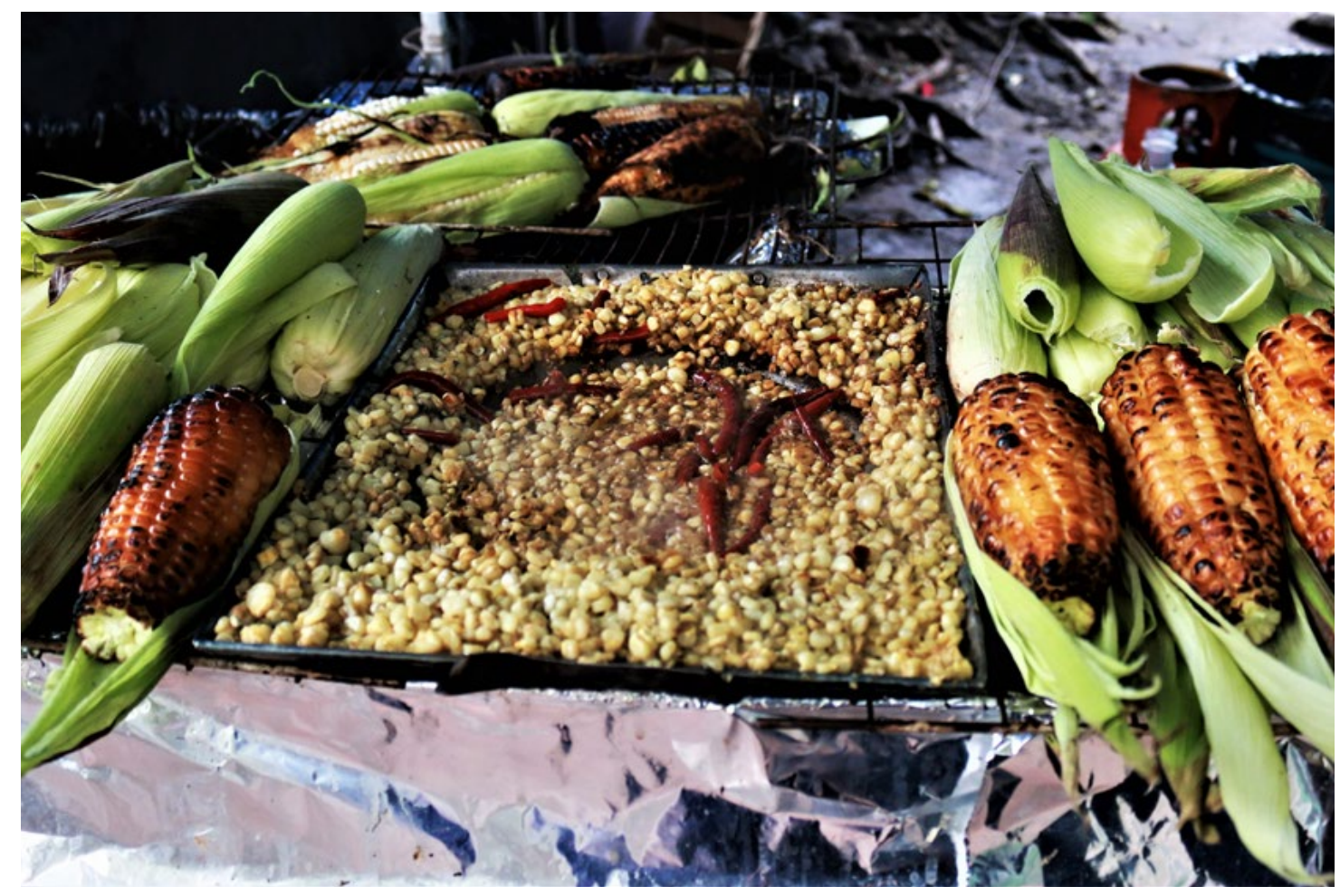

